\title{
Missing in Mexico: Denied victims, neglected stories ${ }^{1}$
}

\author{
Sylvia Karl \\ Department of Cultural and Social Anthropology, Philipps University Marburg, \\ Deutschhausstraße 3, 35032 Marburg, Fax: 0049-6421-2822140 \\ e-mail: sylvia.karl@uni-marburg.de
}

Submitted: 20 September 2014. Accepted: 31 October 2014

\begin{abstract}
In this article, I will describe the mostly invisibilized "fight for rehumanization" of the families of the dehumanized disappeared of the Mexican Dirty War of the 1960s and 1970s. The conflictive memory politics in Mexico and the ambivalent transitional justice process led to processes of re-dehumanization for the families of the disappeared. Within these processes of clarification of past crimes, new spaces of violence emerged. The current "war on drugs" has caused an unprecedented number of new cases of disappearances. I will argue that there are continuities between the Dirty War in the past and the Dirty War practices within the present conflict. In this complex context of violence, the disappearances take place in a battlefield with blurred boundaries: disappearances for political reasons are intermingled with cases of disappearances due to organized crime and new fights for the rehumanization of the disappeared have evolved. In this climate of terror and fear, the families of the disappeared - those of the past and those of the present-are crucial counter-memory groups that object to official discourses that deny the crimes committed by the state.
\end{abstract}

KEYWORDS: Enforced disappearance; dirty war; rehumanization; transitional justice; memory; war on drugs

Citation / Cómo citar este artículo: Karl, Sylvia (2014). "Missing in Mexico: Denied victims, neglected stories". Culture \& History Digital Journal, 3(2): e018. doi: http://dx.doi.org/10.3989/chdj.2014.018

RESUMEN: Desaparecidos en México: Víctimas olvidadas, historias negadas.- En este artículo, describiré la "lucha por la rehumanización" - en su mayoría invisibilizada- de las familias de los desaparecidos deshumanizados de la Guerra Sucia mexicana de los años 60 y 70. Las políticas de memoria conflictivas en México y el proceso de justicia transicional ambivalente llevaron a procesos de re-deshumanización de las familias de los desaparecidos. Dentro de estos procesos de clarificación sobre los crímenes pasados, nuevos espacios de violencia han emergido. La actual "guerra contra el narcotráfico" ha causado un número sin precedentes de nuevas desapariciones. Argumentaré que hay continuidades entre la Guerra Sucia en el pasado, y las prácticas de Guerra Sucia en el conflicto presente. En este complejo contexto de violencia, las desapariciones por razones políticas se mezclan con casos de desapariciones causadas por el crimen organizado, y nuevas luchas por la re-humanización de los desaparecidos han evolucionado. En este clima de terror y miedo, las familias de los desparecidos -las del pasado y las del presente- son grupos de contra-memoria cruciales que rebaten los discursos oficiales de negación de los crímenes cometidos por el Estado.

PALABRAS CLAVE: Desaparición forzada; guerra sucia; rehumanización; justicia transicional; memoria; guerra contra el narcotráfico

Copyright: (C) 2014 CSIC This is an open-access article distributed under the terms of the Creative Commons AttributionNon Commercial (by-nc) Spain 3.0 License. 


\section{INTRODUCTION}

And so we live with this big nightmare [...]. They say the government is the representative of the people, don't they? But they mistreated us and that's why we don't believe in them anymore [...] They took away a family member of ours and in doing so, they left an open wound that will never close (Rosa Castro Velázquez, sister of a disappeared person, San Vicente de Benítez, 2009).

Doña Rosa, quoted above, is one of the relatives of the disappeared of the Mexican Dirty War of the 1970s who has been requesting, since the moment of the forced disappearance of her brother, clarification regarding his whereabouts. She has lost all trust in the Mexican government. Until today, Doña Rosa has received no answer as to whether her brother is dead or alive, whether he was detained in one of the many clandestine prisons across different regions, whether he was tortured and executed, thrown into the Pacific Ocean in one of the death flights carried out by the Mexican military, or inhumed in one of the many secret mass graves that allegedly exist in Mexico and which remain unexhumed to this day. With one exception. In 2008, an alleged mass grave in the former military camp of Atoyac de Álvarez in the state of Guerrero was uncovered. The excavation was carried out by the Mexican government because of a verdict delivered by the Inter-American Commission of Human Rights (ICHR). The ICHR demanded that the Mexican government search for the human remains of Rosendo Radilla, a peasant from Atoyac de Álvarez who-just like Doña Rosa's brother - was disappeared by the military in 1974. But, in contrast to many important exhumation projects, such as those carried out in Spain (Ferrándiz, 2010), neither has there been any reliable exhumation carried out so far in Mexico, nor have any human remains been returned to the families of the disappeared.

This episode in the long-standing struggle of the relatives of the disappeared on behalf of their loved ones is just one example of the conflictive transitional justice process in Mexico. In contrast to the widespread memory politics and cultures of remembrance in former Latin American military dictatorships such as Argentina or Chile (Robben, 2005; Gómez-Barris, 2009), the Mexican case is different, as will be shown. The case of Rosendo Radilla is emblematic of the disappearances in Mexico, and although he is one of the victims that at least gained a public presence, the rest of the approximately 1,220 disappeared of the 1970s, and their families, are fairly forgotten by the public. Also, the exact number of the Mexican disappeared is not clear, since family associations believe that some people did not dare to register the abduction of a relative because of fear of reprisal. Seemingly simple answers about the whereabouts of their disappeared are denied to family members and the state keeps the families and the disappeared in a state of permanent liminality. The Mexican women who keep asking about and searching for the missing are reminiscent of Antigone, as Sant Cassia (2007) refers to the searching women of the disappeared in Cyprus.
In this article, I want to emphasize the mostly invisible "fight for rehumanization" (Karl, 2014; 2014a) in which the families of the dehumanized disappeared participate, the conflictive memory politics in Mexico and the ambivalent transitional justice process. I will briefly describe the initial intent of clarification sought in the cases of the disappeared by the government in the late 1990s while Mexico was still under the Party of the Institutionalized Revolution (PRI) regime. It was not until the era of "change" in the year 2000, with the transition to the PAN government and the establishment of a Special Prosecutor's Office (FEMOSPP), that a widespread transitional justice process started. But, as will be shown, the transitional justice process "a la Mexicana" as Acosta and Ennelin (2006) describe it, led to systematic re-dehumanization for the families of the disappeared. In the last part of the article, I will argue that there are phenomena of continuities between the Dirty War in the past and Dirty War practices within the current "war on drugs". I will show that the current war on drugs has caused an unprecedented number of new cases of disappearances. In this complex context, the disappearances take place in a battlefield with blurred boundaries, disappearances for political reasons are intermingled with cases of disappearances due to organized crime and new fights for rehumanization by the families of the disappeared have evolved. I will show that, whereas there were no excavations of mass graves of the past Dirty War, there are a high number of excavations of mass graves within the "war on drugs"; even so, these exhumations are not without problematic attributions, since the exhumed victims are all included within a political discourse of criminalization.

\section{DEHUMANIZATION: THE MEXICAN DIRTY WAR}

Because he spoke on behalf of the poor. That is why [the government] hated him. Because he spoke for the poor! (Doña Florentina, wife of a disappeared person, Atoyac, 2008).

Doña Florentina is refering to one of the most popular rural guerilla leaders in Mexico, Lucio Cabañas Barrientos, who, in 1967, founded the Party of the Poor (Partido de los Pobres, PdlP) in the Sierra de Atoyac de Álvarezin the southern state of Guerrero. Atoyac de Álvarez was the municipality that suffered most from state repression during the Dirty War. As Doña Florentina states in the above quotation, from the perspective of the victims, it was a war against the poor and marginalized who organized themselves into armed and civil opposition groups against the PRI government. The Mexican Dirty War is a somewhat forgotten event, both in Mexican and international conflict recollection. For the families of the disappeared though, this conflict is quite the opposite of a forgotten era.

In thinking of political violence and Dirty Wars in Latin America, Mexico is not often the first country to come to mind. But as in other Latin American countries, like Argentina, Chile or Guatemala (Robben, 2005; Jelin, 
2003) counterinsurgency wars also took place in Mexico in the context of the global Cold War. In contrast to other countries, where violence occurred under military dictatorships, the violence overseen by the PRI regime against political opposition groups was carried out selectively, focusing only on certain social groups and mostly hidden from the general public (Rangel, 2011; Katz, 2006). The selectiveness of the repression meant that most Mexicans, as well as the international public, did not learn about the disappearances, torture, extralegal killings or the suffering of people affected by state violence. The Mexican Dirty War had its seeds in the context of different social groups demanding specific rights in the 1950s and 1960s. This included protests by railway employees, teachers, doctors, peasant farmers and students. Instead of dialogue, negotiation and the recognition of the existence of social inequality and the marginalization of certain sectors of the Mexican population, the PRI government responded to the demands with persecution and repression of these social movements.

Owing to the rise in violence against them, several of the members of these movements radicalized their own actions and founded armed guerrilla movements. About thirty armed urban and rural guerilla groups arose in 23 states of Mexico. Among them were the Liga Comunista 23 de Septiembre and the Fuerzas Revolucionarias Armadas del Pueblo. ${ }^{2}$ All these groups were persecuted with methods of counterinsurgency that transcended legality (Montemayor, 1998; Mendoza García, 2011). Moreover, the military and a paramilitary group called Brigada Blanca - formed by the secret police or Federal Security Directorate (Dirección Federal de Seguridad, DFS) carried out two particularly cruel massacres: the massacre of Tlatelolco in Mexico City in 1968, against students who were protesting against repressive education policies, and the massacre of Corpus Christi in 1972. These acts were justified as defending national security, as part of the fight against international communism and the destructive ideas of foreign ideologies that penetrated Mexican society. Everybody suspected of sympathizing with these ideologies was persecuted, tortured and killed.

The reprisals were part of a process of dehumanization of the people who were classified as criminals and "dirty" elements that destroyed the Mexican nation. All practices and methods implying physical, psychological, symbolical and/or structural violence that aim at the violent abasement of people, are regarded as processes of dehumanization (Esmeir, 2006; Maoz and McCauley, 2008). In this sense, members of political opposition groups have been classified as sub or non-humans. They have been subjected to discourses of animalistic behavior by the power holders which have served as a justification for violent acts against them. From the perspective of the PRI regime, the members of opposition groups were considered as being outside adequate human categories, values and norms. The counterinsurgency war was, in the official PRI discourse, a justified fight against the "gavilla" (bandits) and "asaltacaminos" (looters) (Mendoza Garcia, 2011).
As mentioned above, the regions most affected by state violence were the villages in the mountainous Sierra de Atoyac (municipality of Atoyac de Álvarez) in the state of Guerrero. In these villages, the armed peasant movement Party of the Poor (PdlP) started to organize against the structural violence of marginalization and repression by the federal government, as well as the local and repressive $\mathrm{ca}$ ciques - the political and economic elite allied to the PRI. The PRI government under President Luis Echeverría (1970-1976) sent about 25,000 soldiers to the region to persecute the members and sympathizers of the PdlP. The military applied the well-known strategies of counterinsurgency in those areas, seeking to undermine local agitation and participating in the dehumanization of the population: checkpoints, control of movement of the civil population, interrogations, restriction of food supply, selective and arbitrary detentions, torture, extralegal killings, disappearances and death flights (Castellanos, 2007; Bellingeri, 2003). Don Margarito of the village of El Escorpión recalls: "We were surrounded [by soldiers]!"(2010). "They wouldn't let anybody out", Don Simon from the village of El Nanchal recalls (2010). And Doña Rosa from the village of San Vicente de Benítez remembers how "You didn't see any other people on the streets, only soldiers!" (2009). The events are referred to by the peasant farmers in the Sierra as "los tiempos feos" (the ugly times) and until today the psychological and direct violence caused by the military occupation still forms part of daily conversations and the collective memory. ${ }^{3}$ About 470 people were disappeared from the villages in the municipality of Atoyac de Alvarez (López y Rivas, 2012). Some were thrown into the Pacific Ocean on death flights that started from the coastal military camp of the nearby Pie de la Cuesta, a site where the detainees received the "coup de grâce" before their bodies were loaded into the airplanes and then thrown into the sea. Others are believed to have been hastily buried in secret mass graves in the military camp of Atoyac de Álvarez and elsewhere.

Another practice by the military frequently mentioned by people in this region, is denying families chance to retrieve the bodies. If there was a confrontation between the guerilla and the military, the soldiers would not allow people to take possession of the corpses to give them a proper burial. Don Simon, for example, recalls: "The government [term used for soldiers] was very aggressive. They didn't allow us to bury them. They said: The dogs will eat them!" (El Nanchal, 2010). These processes of dehumanization against certain social sectors on the margins of the state (Das and Poole, 2004) were not only carried out in the state of Guerrero, but in every region where civil and armed opposition groups evolved (Castellanos, 2007). These events were mostly hidden from public opinion. Hardly any media - most of them controlled and censored by the PRI government (Rodríguez Munguía, 2007) - reported on the violations of human rights and the crimes against humanity perpetrated by state agents. The most significant group in keeping alive the memory of the victims of the Dirty War and in constantly trying to bring the issue to public awareness were the 
families of the disappeared. This memory group transformed the painful state of liminality into political agency, becoming one of the most important counter-memory groups in Mexico. The relatives of the disappeared, besides being victims and survivors, also became human rights activists as will be shown in the following section.

\section{FIGHTS FOR REHUMANIZATION: THE MEMORY GROUP OF THE FAMILIES OF THE DISAPPEARED}

If there was no organization such as ours, who knows, maybe nobody would know about the disappeared (Doña Angelica, Mexico City, 2009).

Doña Angelica affirms a fact that can hardly be ignored. Only the claims, protests and demands of the families of the disappeared have raised awareness about the people who were abducted (Fig.1). The crime of enforced disappearance is, as Citroni and Scovazzi (2007: 17) put it, a "perfect crime", characterized by invisibility, secrecy and impunity. There is neither evidence of the perpetra-

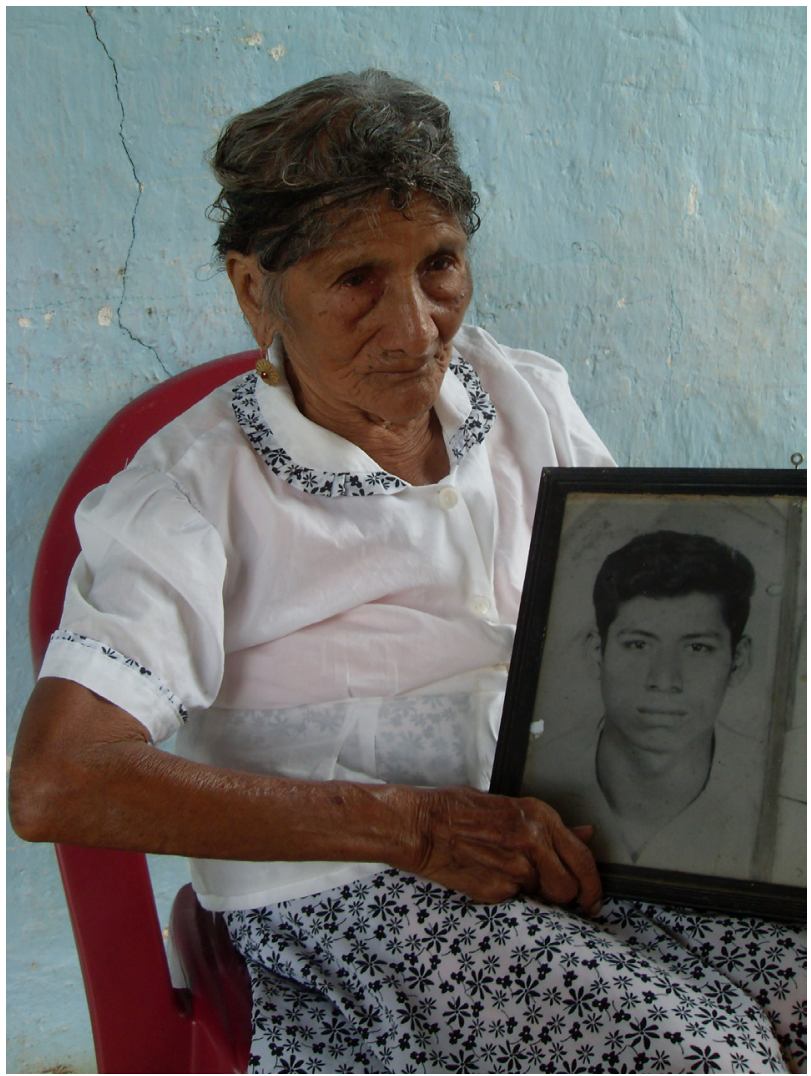

Figure 1. Romana Bello Cabañas holds a picture of her son. He was disappeared by the military in 1974 in Atoyac de Álvarez, Guerrero. Since the 1970s, she has been calling for clarification of his whereabouts, has been part of family associations of the disappeared and has participated in many protests. Because of her old age, it is now her grandchild Rodrigo - the son of the disappeared - who continues the fight for rehumanization (Picture: Sylvia Karl) tors nor testimony of the abducted and eliminated person. It is a crime that officially never happened. Hence the importance of the fight of the families of the disappeared, as Luisa Pérez, a lawyer of the Mexican Human Rights Commission of the United Nations states: "Without relatives there are no disappeared" (Mexico City, 2009). Without them, the history of the Dirty War would, still today, be an episode forgotten by society and negated by the Mexican state.

I wish to argue that the relatives of the disappeared transformed their suffering and sorrow into a political agency that aims to rehumanize the disappeared. Different authors have used the term rehumanization to describe diverse counter-practices against violent processes of dehumanization. Ferrándiz (2009), for instance, uses the term in the context of the rituals that families carry out after the exhumations of mass graves in Spain; Oelofsen (2009) applies it to the recognition of victims through the South African Truth Commission and David and Jalbert (2008) to the counter-movements against racist discourses against Muslims in the United States. Here I am using the term rehumanization in a broad sense to describe all the long-standing practices, discourses and strategies that the families of the disappeared have developed to symbolically undo the dehumanization of the disappeared and which aim to re-integrate the disappeared into the social fabric. Below, I will show some aspects of this fight for rehumanization that resulted from a forced and permanent state of liminality of the families of the disappeared.

The chronic ambiguity, as Afflito and Jesilow (2007) describe the emotional suffering experienced by the relatives of the disappeared in Guatemala, can be considered worse than the initial loss. Doña Estela, sister of a disappeared person from the village of El Quemada said desperately, "If I could only give him a funeral, just as it is supposed to be, it would be a lot easier for me!" (El Quemado, 2010). She also makes reference to the importance of death rituals, important in every society but especially in the Mexican context where there are elaborate death rites, that not only are carried out at the funeral but every single year after the person has been buried. It is believed that the soul of the dead person returns to visit the family every $1^{\text {st }}$ of November. The families receive their dead with food, drinks, new clothes, music and flowers (Brandes, 1998, Lomnitz, 2006). In applying the crime of enforced disappearance, the state denies the victims these important mortuary and memory rituals.

The denial of answers, the denial of mortuary rituals and the denial of mourning processes is a form of psychological torture that leads to a permanent state of liminality. The liminality is experienced as the permanent presence of the absent disappeared. It is a state of betwixt and between, as Turner (1967) describes the state of liminality in rites of passage. Rites of passage are important rituals that people in different cultural contexts perform to come to terms with changes in life, such as the death of a loved person (Van Gennep, 1961). To counter this state of liminality, the relatives "desperately 
sought in vain to alleviate their anxiety" (Afflito and Jesilow, 2007: 68). The constant claims for the presentation of the dehumanized disappeared, the showing of photographs in public, the giving of testimony, as well as the narratives about the disappeared, can all be classified as processes of rehumanization undertaken by the relatives of the disappeared. These practices of rehumanization go further than the mere revisibilization of the disappeared, since they aim not only at making the disappeared visible by exhibiting their photographs in public spaces but at re-integrating them into the social fabric as people. These social practices comprise for example calling out their names in public spaces followed by the collective exclamation "Present!", meaning that the disappeared are still part of Mexican society. Another social practice of integration is recounting their specific biography in public and private spaces: the narratives of the life and work of the disappeared give them back their identity and re-integrate them into a specific social context, such as a family or working network. Stories about their lives are written and published in newspapers, such as in the periodical of the family organization Comité Eureka. The "catastrophe of identity" as Gatti (2008) calls the crime of enforced disappearance, is symbolically undone by the actions of the families. The fight for rehumanization aims at giving their stolen identities and their eliminated dignity and humanity back to the disappeared by performing political rituals in public spaces against oblivion and denial (Karl, 2014). One other important aspect of the relatives' struggle is the constant demand for the punishment of the perpetrators and, moreover, the demand that their abducted relatives should no longer be considered criminals and terrorists, but social activists, people who fought for the rights of all Mexicans during the Dirty War. All these practices are part of the fight for rehumanization, a process which started in the $1970 \mathrm{~s}$, as will be outlined below.

Soon after the illegal detentions of the 1970 s, relatives of the disappeared started to search for them in official and institutional places. As Doña Apolinar remembers: "I left no stone unturned to find my husband" (Atoyac, 2009). In the process of what were initially individual searches in different regions of the country and the subsequent negative answers from the authorities regarding the whereabouts of their kidnapped relatives, those conducting searches realized that their problem was not unique, and that other families were suffering the same uncertainty. They found out about each other, when they met at police stations, at military camps, at hospitals or at government offices searching for their disappeared relatives. As a consequence, the families of the disappeared started to organize. In 1977, the first association of relatives of the disappeared was founded: the Frente Nacional Contra la Represión (FNCR). That same year, the families of the disappeared organized their first hunger strike in the main square of Mexico City. The strikers demanded that the authorities reveal the whereabouts of their disappeared loved ones. "There is no democracy with disappeared persons", "Where are they?", "We will find them!" were the slogans on their posters. Photographs of the disappeared were shown for the first time in the public square. Another poster from that time said: "The mothers don't cry anymore, they fight now!" The relatives transformed the terror, anxiety and the uncertainty about the whereabouts of their families into political action. The organization was later named Comité Eureka when they achieved the release of 148 secretly detained disappeared persons in 1978. The change of name was a strong metaphor that reflected the success of having achieved the release of these prisoners: Eureka means "I found" (Maier, 2001).

In the municipality of Atoyac de Álvarez, in 1978, the families of the disappeared in the rural villages most affected by state violence also formed an association, initially called Comité Nacional Independiente Pro Defensa de Presos Perseguidos y Exiliados Politicos de Mexico and later renamed Asociación de Familiares de Detenidos Desaparecidos y Victimas de violaciones a los Derechos Humanos en México (AFADEM). Tita Radilla, the daughter of a disappeared person, became their president (Díaz, 2011). ${ }^{4}$ It was this organization that, decades later, achieved the first verdict of the Inter-American Human Rights Court against the Mexican state, in the case of the disappeared Rosendo Radilla, of which I shall say more later.

Over the years and through to the present day, despite threats and censorship by state agents - these associations constantly brought the issue of the disappeared to public attention. Since the 1970s, successive governments have assured them that they would shed light on all the cases involved, but, as we will see in the next section, this false rhetoric of cooperation was only used as a way to keep the relatives in an eternal pattern of waiting and hoping. "They will wait until we are dead so that no one will be left to make any more demands!" as Doña Maria, daughter of a disappeared person from Atoyac, said angrily in 2009. The next sections will follow the different phases of governmental response to the families of the disappeared in order to show the ambivalence of their memory politics.

\section{STORIES OF BROKEN HOPES: INVESTIGATIONS ABOUT THE DISAPPEARED IN THE PRI-ERA}

I came here to tell these women, who beg me for the liberty of their husbands and sons, that we will investigate every single case, that we won't help anybody who committed a cowardly murder, but that we will certainly help everybody who has become the victim of an act of injustice (Luis Echeverría cited in Castellanos, 2007:165f).

President Echeverría made this promise in 1975 when he visited the devastated municipality of Atoyac de Álvarez. He stood in the main square of Atoyac where the families of the disappeared were asking for clarification regarding the whereabouts of their disappeared family members. One woman shouted at him, "I want to see my son. He was only working in the corn field" (Martínez 
cited in Castellanos, 2007:165). Not only were there families of the disappeared who were persecuted because of their alleged involvement with the Party of the Poor, but also other families, including a group of mothers and wives of 34 disappeared soldiers. They shouted at President Echeverria, "Do the lives of our husbands and brothers have no value? Does the blood of our fathers and brothers not have the same value as that of other people?" (Castellanos, 2007: 166). The issue of disappeared soldiers is still a rather taboo subject within Mexican society. Neither the government nor the relatives of the disappeared tend to speak about it. The military caused the disappearance of not only the political opposition but also the soldiers who were involved in their torture, murder and disappearance. It is widely believed that these soldiers were murdered and disappeared in order to hide any information about these criminal acts.

Although, in 1975, President Echeverría made assurances in Atoyac that he would look into the whereabouts of the disappeared, there was no real intent to conduct any investigations. It was only fourteen years later that any such attempt was made. PRI President Carlos Salinas, who won the presidential election in 1988 , but was accused of electoral fraud after the election, adopted global human rights discourses and tried to gain the support of the population. One year later, he created the Commission of Human Rights (Comisión de Derechos Humanos, CNDH), the first governmental institution in Mexico to report human rights violations. At the start of this initially promising project, the families of the disappeared of Comité Eureka transferred the documentation of 529 cases of disappearances to the CNDH (Sáenz Carrete, 2001). In 1990, Carpizo, the chairman of the CNDH, founded the Program of Presumed Disappeared (Programa de Presuntos Desaparecidos, PREDES) whose objective was to gather information about the situation in Guerrero and write a final report over the course of two years (Sáenz Carrete, 2001).

For the first time, government officials were sent out to the villages of the district of Atoyac to collect testimonies about the disappeared. But the families of the disappeared stopped cooperating with the $\mathrm{CNDH}$ as they saw that members of the Human Rights Commission started to delegitimize families' claims, saying that some of the testimonies were lies. The CNDH also started to spread false information about the disappeared. Rumors emerged that some presumed disappeared had actually left their families and were living in other states or foreign countries; such misinformation was untrue, as relatives confirmed (Maier, 2001). With these procedures, the government reduced the problematic of enforced disappearance to a personal matter. The CNDH did not clarify any of the cases of disappearance and made no attempt to exhume mass graves. It was not until the so-called transition in the year 2000, which marked the end of 71 years of the PRI regime, that a wider process of investigations was established and the transitional justice process began. It was a process that led to the further revictimization of the families of the disappeared, as I will argue.

\section{RE-HUMANIZATION: TRANSITIONAL JUSTICE A LA MEXICANA IN THE PAN-ERA}

Fox claimed he would clarify everything, but no, that was never his aim! It was only a charade. [...] We know that the commission [FEMOSPP] is actually the government and the government won't punish itself, will it? There has to be somebody from outside to judge them (Doña María, daughter of a disappeared person, Atoyac, 2010).

With these few words, Doña Maria describes the opinion that families of the disappeared had regarding the commission that would supposedly shed light on the crimes of the past. What started in the year 2000 as a process full of hope that emerged in reaction to the far-reaching promises made by the Mexican transition government, ended as a story of frustration, with the re-victimization of the families of the disappeared who received no answers about the whereabouts of their relatives. Moreover, instead of being treated with respect as victims, they were largely denigrated by government officials, threatened, delegitimized as liars, treated as a source of irritation or simply denied their importance as social actors. The transitional justice process "a la Mexicana", 5 therefore, is a continuation of past dehumanization processes, or what we might call the "re-dehumanization" of victims. Re-dehumanization is defined here as a symbolic process inflicted on the victims through arbitrary political measures that reinforce the culture of impunity for perpetrators and lead to the re-victimization of the families of the disappeared. Some examples of these conflictive processes will be described below.

In 2001, in a promising speech at the National Archive, the president who led el cambio (change), Vicente Fox, declared, "In the search for the truth of what happened historically, the contribution of women and men who refused to forget, was crucial [...]. Justice, awaited for decades, is now beginning to become reality" (President Vicente Fox, La Jornada, 27 November 2001). President Fox's political discourse of "change" included democratization, human rights and an "opening up to the world" (Aguayo and Treviño, 2007). It also included appropriate handling of the crimes of the past and the recognition of the claims of the families of the disappeared. Fox announced the implementation of a Special Prosecutor's Office for Social and Political Movements of the Past (Fiscalía Especial para Movimientos Sociales y Politicos del Pasado, FEMOSPP) (Aguayo and Treviño, 2007: 720).

From the beginning, it was clear to many families of the disappeared that this commission would not work honestly and transparently. In particular, they severely criticized the fact that they were not included in the decision-making process. According to Rosario Ibarra, mother of a disappeared person and a representative of Comité Eureka, "To disregard the independent organizations is a grave mistake, since it is only because of the efforts of civil society that the subject of the disappeared has not been forgotten" (cited in Ravelo, 2002). ${ }^{6}$ These practices of disregard and marginalization of the victims were also 
part of a process of re-dehumanization for the families of the disappeared. But despite the criticism, in 2002 FEMOSPP started work with a team of 25 officials from the Secretary of the Interior, a team of experts that consisted of six independent social scientists and a committee (Comité Ciudadano) that was responsible for making contact with the civil population. The FEMOSPP established that the investigation of crimes of the Dirty War would cover three presidential periods: those of Gustavo Díaz Ordaz (1964-1970), Luis Echeverría (1970-1976) and López Portillo (1976-1982). There would be two lines of investigation: the uncovering of acts regarding the massacres in Tlatelolco in 1968 and in Corpus Christi in 1971, and the clarification of all cases of disappearances in the country.

Also, for the first time in Mexican history, criminal proceedings were begun against a former president. Expresident Luis Echeverria was accused of crimes against humanity, homicide and genocide during the Dirty War. Echeverría, for his part, denied he was guilty of any crime. With regard to the massacre of Corpus Christi, the former president said in court, "[In Mexico] there were neither murdered, nor disappeared nor abducted people" (cited in Vera, 2002: 24). As it was widely expected, in 2009 he was exonerated of the crimes by the judges of the Supreme Court. The criminal proceedings against the man presumed to be the main perpetrator of enforced disappearances were no more than a sham, according to the angry relatives of the disappeared in Atoyac. For them, the false statements of ex-president Echeverría and the all-encompassing protection of his person by the government, were once again part of a process of re-dehumanization for the victims.

A further element of re-dehumanization has been the continuity of a deep-seated culture of impunity for former power holders or those responsible for crimes against humanity. This culture of impunity was observed in the criminal proceedings against General Mario Acosta Chaparro and General Francisco Quiróz Hermosillo. In the criminal proceedings on the crimes of the Dirty War, the relatives of 22 disappeared persons from the district of Atoyac were called upon to testify in a military court in Mexico City. The names of those 22 people were on an execution list drawn up by Acosta Chaparro. Don Mario, the son of one of the people on Chaparro's list, had testified in court: "General Acosta Chaparro recognized that he was responsible for the 22 that were on his list and that he only obeyed orders [...] But they let him go free anyway" (San Vicente de Jesus, 2014). The testifying relatives were angry, since the general had recognized his involvement. In an interview, General Acosta Chaparro himself said the following about the acts of torture he carried out:

I have felt what it means to take away the life of somebody, and I am proud to say that my hands did not tremble. And I am not afraid to carry out torture, since I know that the aims that I follow are higher ones: the persistence of a system where we can achieve any imaginable common welfare (Solís Téllez, 2010). ${ }^{7}$
Doña Elvira, sister of a disappeared person, also testified in court. She said it was terrifying to be up in front of the generals in the military court. She recalls, "Everything [the court] was full of military [personnel]. And Acosta Chaparro didn't say anything. Nothing!" (Los Llanos de Santiago, 2007). She was angry because the judges and lawyers asked strange, confusing questions to intimidate her, asking if her sister suffered from mental illness and if this was the likely reason she disappeared. Again, the claims of the families of the disappeared were delegitimized and the acts of disappearance were reduced to the alleged personal problems of the relatives. Such arbitrary proceedings are part of processes of re-dehumanization of the relatives insofar as, once again, neither the disappeared nor the relatives of the disappeared were recognized as victims and the perpetrators, also once again, were protected by the government.

Another example of the ambiguous and conflictive transitional justice process and the re-dehumanization of the victims was the murder of an important witness of the incidents during the Dirty War in Atoyac. Zacarías Barrientos was murdered in 2003, just one day before he was due to testify at the FEMOSPP office in Atoyac. Zacarías Barrientos was a peasant from a small village in the mountains of Atoyac. In the 1970s, he was forced to collaborate with the military as an informer (or "madrina" as it is known locally). He was required to hand over the names of people that were supposedly part of the guerrilla PdlP and accompany soldiers to checkpoints and military camps. In this coerced position, he was believed to have a lot of information about alleged perpetrators, prisoners and subsequently disappeared people. His assassination and the subsequent cover-up of the perpetrators of this crime were therefore associated with his thwarted testimony at the FEMOSPP. Relatives of the disappeared considered this yet another state crime against the victims of the Dirty War. ${ }^{8}$

The incidents surrounding the final FEMOSPP report were indicative of the Mexican government's failing will to respond to victims' claims. At the end of 2005, the scientific expert group's final report entitled Que no vuelva a succeder (It should not happen again) was handed over to Special Prosecutor Carillo Prieto. Over 800 pages long, the report draws on secret records from the Mexican military, intelligence and police agencies. Despite this valuable and groundbreaking report which, for the first time in Mexican history, documents the full range of state violence of the Dirty War, its subsequent treatment is indicative of the lack of political will to recognize victims and establish dignifying memory spaces. After the report was handed over, the government refused to publish the expert group's comprehensive investigations. The incidents surrounding the final report were another attempt to erase the history of the disappeared. Symbolically, the Mexican government had once again robbed victims of their identity, dignity and humanity. It was part of the process of the re-dehumanization of the victims of war. Since the government refused to publish the report, a group of survivors of the massacre of Tlatelolco- the Comite $68-$ 
published the report in the version originally crafted by the group of scientific experts, so that it could finally reach Mexican society as had originally been intended and in the form in which it was meant to be seen (Comité 68, 2008).

As with the conflicts surrounding the final report, FEMOSPP procedures also aroused local anger. In Atoyac de Álvarez, where in 2001 FEMOSPP opened a local office for the relatives of the disappeared to contribute testimonies and information, Doña Andrea, wife of a disappeared person, remembers the frustrating bureaucratic procedures. Like most of the other relatives of the disappeared, she had to travel from her village in the mountains down to the district capital of Atoyac to hand in all the papers:

Every day I went to the office, every single day. [They told me to] go there, and I went there. But all for nothing! A pile of papers, heaps of paper and they came here [her house] as well. They took pictures of me, they brought a computer to take copies of identifications, copies of all the documents I had. And so far, all for nothing (Rincón de las Parotas, 2010).

Like Doña Andrea, other relatives of the disappeared share the same anger and frustration. All of them handed in their own documents and those of their disappeared relatives, they answered questions, they gave testimonies but in the end, the office was closed down in 2006. Questions about the whereabouts of loved ones remain unanswered. The conflictive transitional justice process led to a painful re-dehumanization and revictimization for many families of the disappeared. The reigning power constellations and the paramount influence of the military impeded the recognition of the victims and no answer was provided for their queries. Such processes in Mexico can be considered "transitional frictions", a term Alexander Hinton uses to refer to the "complexities of the encounter between global/transnational mechanisms and the local realities on the ground" (2010: 9). All these ambivalent transitional frictions are part of a state of "liminality of transitional justice" (Karl, 2014). For as long as the lack of answers perpetuates the state of liminality of the families of the disappeared, the national process of transitional justice will be stuck in a similar state of liminality. Despite the frictions and obstacles, many relatives of the disappeared continue their fight for rehumanization, as will be demonstrated in the following section.

\section{THE FIGHT FOR REHUMANIZATION GOES ON}

We must not forget them; we have to continue fighting for them, although so much time has passed already. Just imagine, one day your brother comes back and sees that we have forgotten him, that we didn't do anything for him anymore that we didn't search for him! Imagine that! (José Luis Arroyo Castro, nephew of a disappeared person in conversation with the relative of another disappeared person, Atoyac, 2009).
In the conversation quoted above, José Luis Arroyo Castro emphasizes to Margarito Mesino, whose brother was disappeared in 1974, the importance of continuing the fight for the abducted. Despite the frustrating political developments surrounding the close of the FEMOSPP office, the denial of answers to relatives, and the exoneration of the perpetrators, many relatives continue to motivate others. While some claim they cannot struggle anymore, that they have no money left, that they are sick, old and disillusioned, others continue the fight and even represent those who have given up or died. They are convinced that the fight for justice has to go on. Judith Herman describes this process as the "mission of the survivors" (1998: 151). In this vein, Apolinar Castro Román, wife of a disappeared person from Atoyac, speaks about the motivation to continue fighting for her husband:

[The] worst fight is the one which is never conducted, isn't it? I continue fighting, if it doesn't lead anywhere, okay, then I will end the days of my life like that: waiting, waiting. Just like other compañeras who died, waiting, waiting and he [the disappeared relative] never returned. But well, I will not lose faith. I still have the hope that maybe... and I beg my god to soften their [the government's] hearts and that they will help us (Apolinar Castro Román, Colonia May 18 ${ }^{\text {th }}, 2009$ ).

Just as the relatives of the disappeared in Atoyac in the state of Guerrero continue their struggle and on a regular basis organize public protests in the district capital, another group of relatives makes the disappeared visible in Mexico City's public spaces. The association of children of the disappeared (Hijos e Hijas por la Identidad y la Justicia contra el Olvido y el Silencio: H.I.J.O.S.), together with Comité Eureka, regularly performs actions known as escraches. H.I.J.O.S. Mexico was founded in 1998 in cooperation with the Argentine organization of the same name. The nation-specific associations of the transnational network of H.I.J.O.S. perform escraches in several Latin American countries. The term escrache has its origins in the colloquial lunfardo language of Buenos Aires, meaning "to bring to light, to make visible" (Becker and Burkert, 2008). The practices of escraches are part of processes of rehumanization of the disappeared since they not only make the missing visible in public spaces, but they also aim at re-integrating their identities into the Mexican society through different social practices. For example, in public squares members of H.I.J.O.S. give passers-by pictures of disappeared persons, take pictures of the person holding the photographs, and publish these in different media spaces. The pictures are intended to say, "We all miss Jorge [the disappeared], Hermilo [the passer-by] misses him, too!"9 At the same time, they constantly bring to public debate the issue of the impunity of the perpetrators of the Dirty War. This rehumanization practice aims to reiterate and underscore the issue of the disappeared so that society continues to be made aware of the matter.

Another escrache action that aims to rehumanize the disappeared is the re-naming of street signs originally bearing the names of presumed perpetrators. ${ }^{10}$ The street 
sign named after Luis Echeverria, for instance, was renamed with the name of a disappeared person. Since October 2008, H.I.J.O.S. and Comité Eureka have also been organizing an escrache in front of the Supreme Court of Justice in the center of Mexico City every first Saturday of the month (Fig.2). The court symbolizes the reigning injustice and impunity in the country. The relatives of the disappeared hang pictures of the alleged perpetrators and their disappeared on the fence in front of the court building. In a conversation with Sara Dúarte of Comité Eureka, wife of a disappeared man, she emphasized the importance of their actions, "It is important that we show the people who we are. Because lots of people think that we come from Argentina and that we are relatives of the disappeared of Argentina" (Mexico City, 2009). Many Mexicans still do not know that people disappeared in the Dirty War, which demonstrates that the transitional justice process that began with the presidency of Vicente Fox did not lead to a widespread public debate about past atrocities, but continued the silencing and negation of the victims. This again highlights the importance of the actions of the families of the disappeared. Like Sara Dúarte, others continue to distribute flyers to passers-by saying: "Because we all miss the disappeared!" or "They took them away alive; we want them back alive!" This widespread slogan used by relatives of the disappeared in Mexico refers to the continuing hope that the disappeared, despite more than 30 years of absence, will one day be returned.

These performances show the permanent fight for the rehumanization of the disappeared, in which the issue of the Dirty War is constantly brought to public debate, even though hardly any Mexican media cover the events. Censorship and silencing still characterize official handling of the past. Aware of this fact, in 2012, Comité Eureka and H.I.J.O.S. opened a private museum in the historical center of Mexico City documenting their actions since the 1970s, and exhibiting photographs of the disappeared. The museum is called "House of the Indomitable Memory" (Casa de la Memoria Indómita) in reference to the irrepressible determination to keep the memory of the disappeared alive, despite all the obstacles that Mexican governments have so far put in their way (Karl, 2014).

The struggle of another group of relatives shows how a long-standing fight for rehumanization could also reap at least a small judicial victory: the case of disappeared Rosendo Radilla, which will be outlined below.

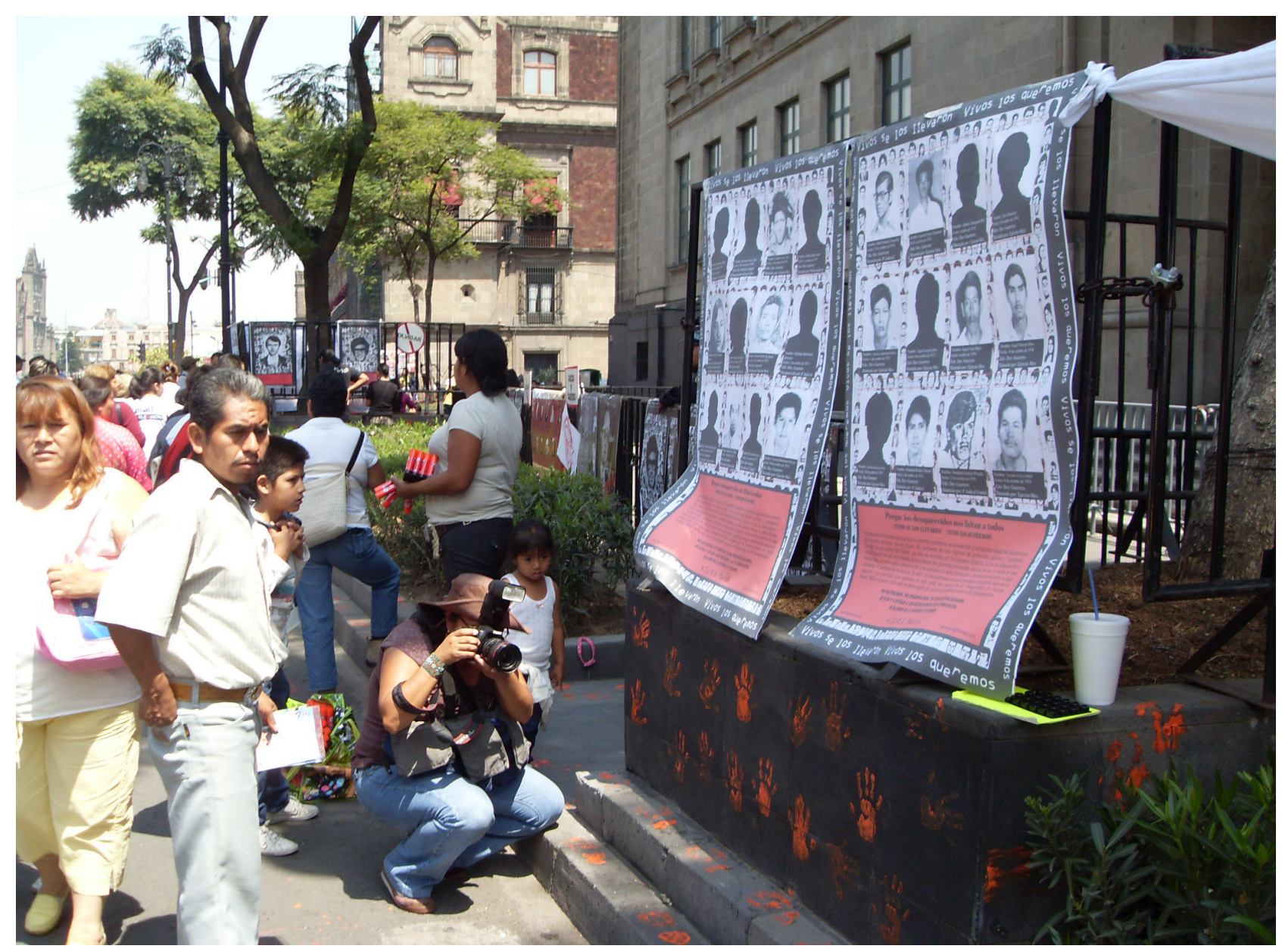

FIGURE 2. The fight for rehumanization. A protest of the families of the disappeared of H.I.J.O.S. and Comité Eureka in front of the Supreme Court of Justice in Mexico City (Picture: Sylvia Karl) 


\section{EXCAVATIONS OF THE MASS GRAVE IN ATOYAC DE ÁLVAREZ: THE CASE OF ROSENDO RADILLA}

One of the most emblematic and visible struggles for the rehumanization of a disappeared person is the case of Rosendo Radilla. In August 1974, the military detained Rosendo Radilla Pachecho at a checkpoint. A peasant farmer from Atoyac de Álvarez, he was active in social movements fighting for the rights of peasant farmers in the region and later became mayor of Atoyac. He also composed popular corrido songs, one of which he dedicated to Lucio Cabañas, the guerilla leader of the Party of the Poor. When he was arrested, Rosendo Radilla was accompanied by his son who remembers his father asking the soldiers why they were detaining him. Their only answer was that he composed corridos for Lucio Cabañas (Antillón Najlis, 2008: 15). This arbitrary detention was characteristic of many abductions in Mexico during the Dirty War. Rosendo Radilla's case became emblematic as the first case of a disappeared person accepted at the Inter-American Court of Human Rights (ICHR), owing to the large amount of evidence available. Radilla's family organized their case with AFADEM, which, having submitted complaints to the Mexican government for decades, realized their efforts would be in vain. The family and AFADEM therefore decided to hand the case over to an international court instead. In 2001, together with the Mexican Human Rights Organization Comisión Mexicana de Defensa y Promoción de los Derechos Humanos (CMDPDH), they submitted the complaint to the InterAmerican Commission on Human Rights, which, after an examination of the case in 2008, transferred it to the Inter-American Court of Human Rights. On November $23^{\text {rd }}$, 2009, the ICHR found the Mexican state guilty of the illegal abduction of Rosendo Radilla.

The verdict required the Mexican state to clarify the whereabouts of Radilla and, in the event of his death, to carry out exhumations, hand over the human remains to the family, pay reparation to them, offer a public apology, put up a commemorative plaque in honor of Radilla in a public space and abolish the military's jurisdiction regarding crimes committed by members of the armed forces. ${ }^{11}$ The Mexican government, represented by President Felipe Calderón (2006-2012) had to accept the verdict and fulfill its requirements. By 2008, following the order of the Inter-American Commission on Human Rights, the Calderón government had already started excavating the supposed mass graves in the former military camp of Atoyac de Álvarez, the place where Radilla was seen last by eyewitnesses in 1974. For the sons and daughters of Rosendo Radilla, the search for his mortal remains is the most important aspect in their long standing struggle. They want to retrieve his remains in order to bury him in a proper manner, to have a site of mourning and memory. By achieving this, their father would be properly re-integrated into the social fabric in his role as an ancestor. Only then would he be rehumanized.

The excavation was carried out by officials of the Public Attorney's Office, in cooperation with the Mexi- can team of forensic anthropologists (Equipo Mexicano de Antropología y Arqueología Forense). From the beginning, the forensic team was critical of the fact that their work was obstructed by government officials and that they could not get access to all the areas of the former military camp. Also, they were not allowed to dig where eyewitnesses indicated that there possibly were mass graves. In the end only one percent of the area was examined with geological radars, but the exhumations stopped when the government asserted that there were no human remains. Mexican journalist Gloria Díaz wrote in the journal Proceso: "The exhumations in Guerrero were a sham" (2008) $)^{12}$ María Felix Reyes, a member of the family association AFADEM, criticized the fact that relatives were not allowed to be part of the excavation efforts. Government officials failed to pay attention to relatives' statements about the alleged places where mass graves might be located. Reyes noted:

In the military camp they carried out excavations, but they [government officials] indicated which places were to be dug $[\ldots]$ They are from the government, and they say [we will dig] here, here because they know they won't find anything. That's why I say that they know, but they act like fools. They know everything (María Felix Reyes, Atoyac, 2010).

In the years 2010, 2012 and 2013, the government once again carried out exhumations in the former military camp of Atoyac. But the same arbitrary procedure was employed and nothing was found. ${ }^{13}$ Despite the failed promises and the frustrating discourses and actions of successive Mexican governments, the families of the disappeared continue fighting for the rehumanization of their disappeared loved ones. A further attempt at clarification was also made on a local level. In 2012, the government of Guerrero established a Truth Commission to clarify the cases of disappearances in the state of Guerrero, and mainly in the municipality of Atoyac.

\section{THE TRUTH COMMISSION IN GUERRERO: CLARIFICATION ATTEMPTS IN NEW SPACES OF VIOLENCE}

In 2012, Ángel Aguirre Rivero, Governor of the state of Guerrero, implemented the first Mexican Truth Commission on a local level. While applauding the decision to install a Truth Commission, some relatives of Atoyac's disappeared nevertheless remained mistrustful. After their experience with the National Commission of Human Rights in the 1990s and the frustrating developments with FEMOSPP between 2002 and 2006, they were skeptical that another commission would bring about any better results.

Soon after the setting up of the Truth Commission, which worked for two years, its members went to Atoyac to speak to some relatives of the disappeared. Whereas some saw the visit as a positive event, others, in villages further away from the district capital of Atoyac, com- 
plained that most of the relatives were not being taken into account in the decision-making process and that most did not even know that a new commission had been established. Don Ruben, brother of a disappeared person, complained that they came into his village but did not have the sensitivity to speak to all of them, acting in an arrogant way. He remarked critically: "The Truth Commission, look how they come in here, people we don't know and who don't know how to speak to the people here!" (Los Valles, 2012).

As before, many relatives show a deep-seated mistrust in governmental institutions, and once again felt marginalized and forgotten. Don Mario of the village of San Vicente de Jesús, son of a disappeared person, said in a conversation in 2014, that even after two years of its existence, he still did not really know what the aim of this commission was. They had visited neither him nor several of the other relatives, but instead spent millions of pesos on assemblies, visits and "who knows what", investigating things that were already known. Moreover, a day before the announcement of the final report on October $14^{\text {th }}, 2014$, the members of the Truth Commission claimed that the final phase of their work had been obstructed by the government, that they received threats and that their budget was cut down. These impediments began after the first exhumation of a clandestine grave and the identification of the body of a former disappeared guerrilla member who was killed by the military during the Dirty War (Petrich, 2014). It is widely believed, that the Mexican government did not want any further investigations into the matter. Against this backdrop, it will be difficult for the final report to bring any new information for the relatives of the disappeared. Again, the ambivalences surrounding the work of the Commission only served to reveal the continuing re-dehumanization processes for the victims.

Meanwhile, other developments show the continuing frictions with which families of the disappeared have had to deal. Some of the relatives of the disappeared had small-scale success in 2012, when the federal government started to distribute reparation payments to some of the families. The basis of this decision was the report of the National Commission of Human Rights of 2001 which stated that 274 families of the disappeared should receive reparation payments (Damían Rojas, 2012). Despite this positive announcement, there were risks associated with receiving money. In a meeting with relatives of the disappeared, Don José, nephew of a disappeared person, recalls that officials of the Public Attorney's Office told relatives that, if they received payment, they should not talk about the amount of the money awarded. The reason given was the general climate of violence and the presence of organized crime syndicates colluding with corrupt police and military agents, thus creating a high risk of extortion or kidnapping. A relative of a disappeared person in Atoyac, father of a 14-year old boy, was one of the first to receive reparation. After he received the money, his son was kidnapped. The father paid the ransom, but the kidnappers killed his son anyway. Other rel- atives were also robbed after receiving reparation payments (Valadéz Luviano, 2012b). ${ }^{14}$ In 2012, Don Ruben spoke about other cases of relatives who received reparation payments and who were subsequently threatened.

In this climate of terror and fear, the transitional justice instrument of reparations for crimes becomes, instead of an act of recognition of victimhood, another security risk for the relatives of the disappeared. In this state of insecurity brought about by the so-called "war on drugs", where people do not know whether the risk comes from security agents, or members of organized crime or both, it is hard for the relatives of the disappeared to claim justice. Many feel they are in the midst of another Dirty War, now disguised as the "war on drugs".

These incidents point to the crimes of the past but also to the crimes of the present that have taken place within the so-called "war on drugs". Unlike other post-conflict countries where the majority of cases of enforced disappearances occurred within repressive military dictatorships in the past, in Mexico the new cases of disappearances outnumber the disappearances of the past. In this case, it is hard to distinguish between victims and perpetrators, since disappearances are caused not only by state agents but by organized criminal networks. In these new spaces of violence, associations of families of the disappeared of the past are joining together with new associations fighting for the disappeared of the ongoing "war on drugs". The latter are carrying out their own struggle for rehumanization. In the following section, I will give a brief overview of the current situation, arguing that Dirty War practices from the past are continuing in the present and that the failed transitional justice process in Mexico is partly responsible for this current conflict.

\section{THE "WAR ON DRUGS": A CONTINUITY OF THE DIRTY WAR METHODS?} "They took them away alive, we want them back alive!"
This claim on a banner in a manifestation on October
$2^{\text {nd }}, 2014$ calls for the return of 43 disappeared students
(Fig. 3 ).

On September $26^{\text {th }}, 2014$ police forces in the town of Iguala, in the state of Guerrero caused the disappearance of a group of 43 students. As videos and testimonies showed, they were forced into police cars and then handed over to members of a drug cartel, who supposedly killed some of them. ${ }^{15}$ Days later, bodies were found in several mass graves near Iguala, and are still awaiting identification. Independent forensic specialists, like the EAAF from Argentina, have claimed that the government is obstructing the exhumation and identification of these human remains and preventing independent experts from accessing the area. ${ }^{16}$ When made public, these events caused terror, despair and anger in the Mexican public and showed the continuity of dehumanizing Dirty War methods by state forces. Consequently, at the annual demonstration in Mexico City on October $2^{\text {nd }}, 2014$ in remembrance of the massacre of Tlatelolco in 1968, two 
events were commemorated at the same time: the remembrance of the victims of the Dirty War of the 1960s and 1970 s, and the call for clarification of the whereabouts of the disappeared of the current so-called "war on drugs" (Fig. 3).

As a counter-drug-trafficking policy, with a whole apparatus of security forces, the "war on drugs" has a longstanding historical and political trajectory in different parts of the world with many stakeholders. As was widely circulated in the global media in 2006, Mexican President Felipe Calderón (2006-2012) declared war on drug trafficking. He sent out convoys of military vehicles, helicopters and soldiers to different regions of the country. The president said it would be a war against the powerful Mexican drug cartels, which implemented a violent, so called narco-war, fighting for the control of territories, local and transnational markets, and people. The purpose of the war declared by President Calderón was to reconquer state territories lost to organized crime, for national security purposes, and to protect the human rights of people threatened by brutal drug cartels. Mexican President Enrique Peña Nieto, elected in 2012, is now continuing the
Calderón strategy of combating the cartels with military forces. It is, however, apparent that the government combats not only drug cartels, but political opposition groups as well.

Anthropologist Howard Campbell considers use of the term "war on drugs" as "hypocritical and misleading" (2009:7). In this conflict, there are no clearly defined groups engaged in battle against each other, as the traditional concept of "war" would suggest. On the contrary, different groups within the state and organized crime syndicates fight each other, while other state and illegal agents cooperate to extract mutual benefit from corruption. Although use of the term "war on drugs" poses a dilemma, I will nonetheless use it here, albeit in a slightly different sense, namely to refer to a governmental discourse that disguises counterinsurgency methods similar to the Dirty War of the past. The misleading discourse of "war on drugs" is also apparent in the historical operations of drug cartels in Mexico over the last few decades. Despite these operations, levels of violence and homicide were actually at their lowest in Mexican history before Calderón started to wage his war in 2006 (Aguilar and Castañeda, 2012). It

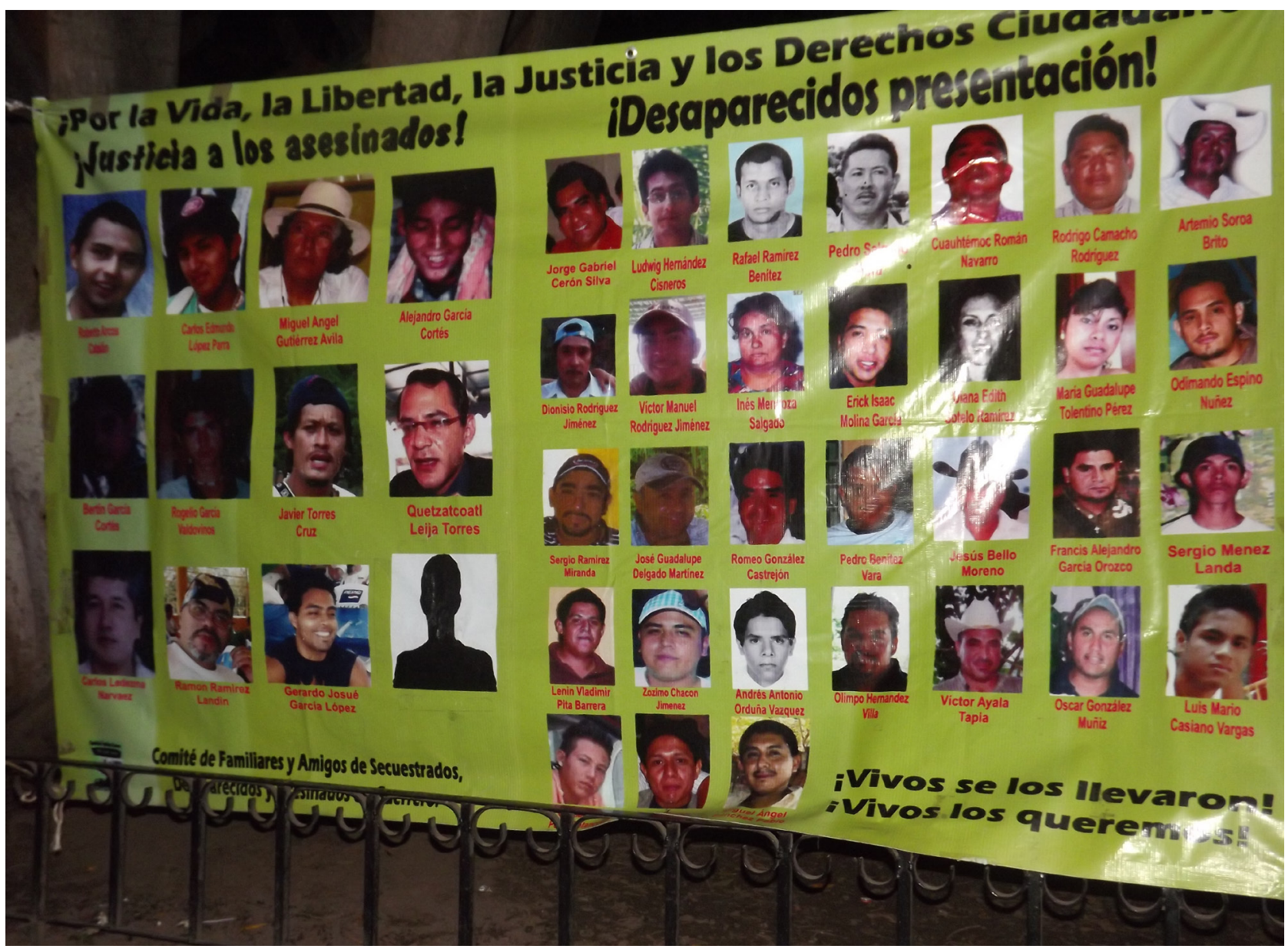

FIgURE 3. On the October $2^{\text {nd }}, 2014$, during the annual march in remembrance of the massacre of Tlatelolco 1968, protesters also demanded clarification about the whereabouts of the 43 students who were disappeared by police forces in the state of Guerrero on the September $26^{\text {th }}, 2014$ (Picture: Sylvia Karl). 
was only with the drug-war militarization strategy that the number of violent acts - including homicide, kidnapping, torture and disappearances - rocketed.

The number of victims that have accumulated since the beginning of this war is not clear, but the Mexican Institute of Statistics states that, as of July 2013, 121,683 people had been murdered (Proceso, 2013) ${ }^{17}$, and by November 2012, the Mexican Interior Ministry had counted 26,121 cases of disappearance. ${ }^{18}$ Human rights organizations can only estimate the thousands of orphans whose parents have been killed or the number displaced when they fled their hometowns because of the violence. As Mexican anthropologist Hernández Navarro puts it, "A war on drugs? No, this is a war on the Mexican people". ${ }^{19}$ Mexican political analyst Carlos Fazio claims that crimes became part of the political system of social control. ${ }^{20}$ The so-called narco-politicos are responsible for a new type of crime that seeks to rid society of all kinds of enemies. I would like to point out that these processes, carried out in the context of the "war on drugs", demonstrate the perpetuation of a system of structural impunity for the perpetrators of crimes. The Mexican military's contemporary war against the drug cartels occurs beneath the façade of the official "war on drugs" which is in fact a new Dirty War. Or, rather, it is the continuation of the Dirty War against political opponents, which began in the 1970s. Carlos Fazio (2011) refers to two concepts similar to the Dirty War of the past in the current "war on drugs": on the one hand, the construction of an internal enemy threatening national security (the narcos) and, on the other, the construction of chaos and fear. Controlled media constantly justifying the militarization of the country support these two concepts. It is, at the same time, a justification for social control and human rights violations - collateral damage on the dehumanizing battlefield of national security. These processes of violence are part of the political control of citizens of what Das and Poole (2004) refer to as the "margins of the state".

From an anthropological perspective, it is crucial to look beyond the official discourses of the "war on drugs" and ask about the social realities in which this conflict takes place and the people that are involved. In particular, we have to ask, how are the new phenomena of violence affecting the civil population and what are the motives behind these violent acts?

\section{NARCO-VIOLENCE, STATE VIOLENCE AND NEW VICTIMS' MOVEMENTS}

They kidnapped him and nobody would tell me anything about the place where they took him. They disappeared him! And I am sure he doesn't have anything to do with the narcos (Teresa, mother of a disappeared son, meeting of Movimiento por la Paz con Justicia y Dignidad, Mexico City, 2012).

The despair of the mother of an abducted son, quoted above, raises an important question in this conflict: are the victims and perpetrators always related to organized crime as the official media accounts offered by politicians suggest? Human rights organizations and victims groups, including associations of families of the disappeared like the Comité de Padres y Amigos de Desaparecidos, paint a different picture. They reject the all-encompassing use of narco-terminology by politicians, security forces and the media, who associate every crime and, hence, every case of a disappeared person, with so-called narcoviolenciathe violence related to drug cartels. Where new cases of disappearance are concerned, it is not always clear who the perpetrators or victims are. The Federación Latinoamericana de Asociaciones de Familiares de Detenidos-Desaparecidos (Latin American Federation of Associations for Relatives of the Detained-Disappeared) calculates that, out of 3,000 cases of disappearances, 400 are for political reasons, 500 are woman and children whose disappearances are related to human trafficking, and 2,100 disappearances are related to drug trafficking.

The acts of violence that have emerged within this conflict are part of new dehumanization practices: burned body parts found in barrels; people hanged on bridges; beheaded and dismembered bodies deposited in plastic bags found near roadways or in public squares; and the remains of hundreds of murdered bodies detected in mass graves. Mexican governmental forensic specialists refer to much of the human remains found as no nombres, or "no names", since they cannot be identified due to their state of decomposition or because the bodies were dissolved in acid. Forensic specialists have developed a routine: agents carry out exhumations, register body parts, and put them into plastic bowls. If identification is impossible and nobody claims the body, they are buried in mass graves. Not being identified or not being claimed means that the dead body disappears into the anonymity of an unknown cemetery, a practice of desocialization and dehumanization of the victims. Mexican journalist Marcela Turati describes the despair of the families:

[E]ntire families travel through the country as if they were a nomadic tribe searching for their dead. Every time they hear about a grave that has been found, they go to the morgues or the forensic services to see if they can identify a family member within the pile of cadavers (Turati, 2011: 10). ${ }^{21}$

In the Dirty War of the 1970 s, the families of the disappeared also searched for their relatives this way, with the only difference being that the number of disappeared was far smaller than it is today. Today's widespread acts of violence cause fear and terror, and lead to a climate of suspicion where mutual trust is waning. People mistrust each other since they believe that even their closest neighbor may have become part of an organized crime group, who may also be collaborating with police or military forces. The consequences of this climate of suspicion are even reflected in the way everyday communication takes place. People who suffered the Dirty War of the 1960s and 1970 s recall a similar climate of fear and mistrust. Now, once again, many prefer to remain silent, as this ex- 
cerpt from a conversation with a woman from the Sierra de Atoyac shows:

Since the Caballeros Templarios [drug cartel] has controlled our villages, nobody is talking and gossiping anymore in the minibuses. Before that we were always talking to each other, exchanging gossip, but now everybody remains quiet, everybody is afraid that there could be orejas [drug cartel spies] sitting there. We don't know, maybe our neighbors are already a part of them (Maria, peasant, Sierra de Atoyac, 2013).

As Maria's comment indicate, the fear of violent acts is associated with media images and narratives that circulate throughout Mexico and that have become part of rumors and social imaginaries. Again, this fear was present in the times of the Dirty War, when people were afraid of becoming a victim of an arbitrary violent act. In all these acts of violence, the same question arises: who are the victims and who are the perpetrators in this conflict? The media and the government refer to these clandestine graves as narcofosas, again connecting all of them to organized drug crime and thus criminalizing every victim. But is this discourse of drug-related crimes and the criminalization of victims always the truth? (Reveles, 2011). In 2011 and in 2014, a United Nations report urged the Mexican government to consider withdrawing its use of the military because of complaints about "involuntary disappearances" 22 (Díaz, 2014a). ${ }^{23}$ The National Human Rights Commission has received more than 5,000 complaints of abuse at the hands of the military. Cartel members often disguise themselves as police officers or soldiers, using fake or even genuine, equipment, stolen or procured from allies in the agencies. This has allowed the authorities to dismiss many disappearances as the work of "clones" (Randall, 2011). Narco-warfare and state terrorism are about violent acts of dehumanization. Malcolm Beith states that Mexican drug cartels like the Sinaloa Cartel are copying the statestrategies of the Dirty War from back in the 1960s and 1970s to get rid of enemies (2010). The adoption of those methods can also be explained by the fact that some former members of the military with knowledge of counterinsurgency methods are working within the drug cartels. One example of this is the paramilitary group Zetas, which is composed of former Mexican special forces soldiers and Guatemalan elite soldiers (Osorno, 2012). The Mexican government also employs drug cartel members as paramilitary death squads to eliminate political opposition. Diego Osorno states that his counterinsurgency strategy was already employed during the Mexican Dirty War of the 1960s and 1970s, when the Mexican government recruited narcos to get rid of guerrilleros and other state enemies (Osorno, 2009).

There is also a shift in terminology when people are kidnapped and disappeared. Instead of the term desaparecer (to disappear), the police and media use the word levantar - which means to pick somebody up - insinuating that this is a different kind of crime, since it was surely perpetrated by drug cartels. But, in many kidnap- ping cases, the population is aware it was an act of enforced disappearance, since witnesses see it being carried out by state agents, such as the police or armed forces. The preference for levantar over desaparecer places victims outside the protection of a law where enforced disappearance is considered a crime against humanity. Victims' associations are therefore claiming that the Mexican state is using the "war on drugs" to get rid of political opponents while holding organized crime syndicates responsible. It is a war without frontlines, a battlefield without any clearly defined players, creating a general climate of suspicion, rumor and silence. Nowadays, state terror crimes merge with the crimes of drug cartels and other criminal networks. The fight between the state and drug cartels for territory and zones of influence is intertwined with the state's classical counterinsurgency methods against political opposition and social movements. In the Drug War Zone (Campbell, 2009), nobody actually knows who is fighting whom and why. But this veneer of confusion serves the purposes of both state and organized crime.

Victim and human rights groups are responding to these crimes. Their protests and complaints are significant acts which pinpoint violent incidents in a publicly visible manner. The associations of the families of the disappeared in the Dirty War of the 1960s and 1970s have joined groups of victims of the new Dirty War. The victims are demonstrating and fighting for the rehumanization of the disappeared and murdered who have been dehumanized (Fig. 4). More than 50 Mexican groups supporting these causes have joined forces, networking with other Latin American victims' groups from Argentina, Chile, Ecuador, Panama and also Spain. In 2011, civil society and victims' groups mobilized into a huge protest movement called "Move-

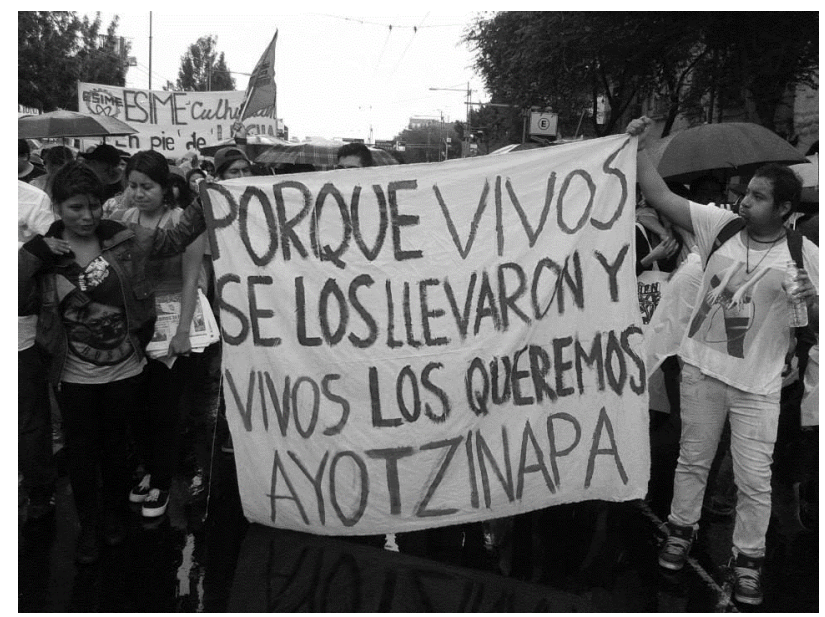

FigURE 4. New struggles for rehumanization of the disappeared in the current "war on drugs". Like the families of the

disappeared in the Dirty War of the 1970s, the families of the disappeared in the ongoing conflict are demanding, "They took them away alive; we want them back alive!" Banner in

Chilpancingo of the association of families of the disappeared Comité de Familiares y Amigos de Secuestrados,

Desaparecidos y Asesinados en Guerrero (Picture: Sylvia Karl) 
ment for Peace with Justice and Dignity", founded by Javier Sicilia, whose son was killed in February 2011. The members of the Movement for Peace with Justice and Dignity organize different protest activities and march constantly through Mexican territory to bring awareness about thousands of forgotten and invisibilized victims (Sicilia, 2011). The importance of their activities, protests and claims is to give public visibility to human rights violations and hold potential perpetrators accountable for their crimes. The victims' groups have confronted the Mexican government with testimonies of the families of those murdered and disappeared; they organized a victims' caravan that journeyed through the United States in 2012; they have called for the re-naming of a monument in Mexico City as a Victims' Memorial and they have handed in reports to international organizations, such as the UN Working Group on Enforced Disappearance. ${ }^{24}$

In this "war on drugs", the governments of Calderón and Peña Nieto again assigned the military an important role in protecting national security. This is one of the barriers to clarification of the crimes committed by state agents, both present and in the past. The reigning power constellation and the continuing culture of impunity hamper any reliable transitional justice process. For the relatives of the disappeared of both the Dirty War of the 1960s and 1970s and the current war, this means a continuing fight for the memory and the rehumanization of the disappeared: "Until we find them!" (Hasta encontrarlos), as one of their slogan's claims.

\section{CONCLUSION}

Since the 1970s, the Mexican relatives of the disappeared have developed different practices and discourses in their fight to ascertain the whereabouts of their disappeared loved ones. It is a fight for rehumanization that aims to reintegrate the dehumanized disappeared into the social fabric. The posters of the relatives of the disappeared demanding, "They took them away alive, we want them back alive", "Until we find them!" and "Where are they?" are part of the protests by Mexican "disappeared" families' associations demonstrating such re-integration practices. They have been confronted with different transitional justice instruments, set up by various Mexican governments on several occasions. All have failed so far. Until now, no answers about the whereabouts of the disappeared have been forthcoming. No serious exhumation project has been carried out. Human remains have not been returned to the families. The alleged perpetrators put on trial were exonerated and the final report of the FEMOSPP commission was never officially published when it could have been a sincere demonstration of recognition for the victims and the historical memory of the Dirty War. The transitional frictions (Hinton, 2010) caused by the reigning power constellation and the culture of impunity can be observed on every level in any attempt to clarify past atrocities. These conflictive transitional justice processes, defined by mistreatment, threats and disrespect for the relatives of the disappeared, have turned out to be processes of symbolic re-dehumanization of the victims, of re-victimization and of neglected stories.

The human rights violations, though, are not only an issue of the past. The long-standing performance practices used by the relatives of the disappeared in the Dirty War of the past are now reappearing on the streets, employed this time by the associations of relatives of the unprecedented figures of disappeared persons in the current "war on drugs". They show photographs of their disappeared family members and loved ones in public squares. They place crosses and flowers in the memory of the disappeared and murdered in public spaces throughout the country. And they demand justice and the end of impunity for criminal state agents.

The "chronic ambiguity" (Afflito and Jesilow, 2007) is again affecting thousands of families of the disappeared in Mexico. As in the past, the Mexican government continues to deny any responsibility for the crimes, spreading a discourse that relates every murder, every case of disappearance and every exhumation of new mass graves to organized crime. Within these spaces of cruelty, uncertainty and fear, the families of the disappeared are fighting for the rehumanization of the forgotten, the invisibilized and criminalized disappeared, both past and present. It is they who keep a crucial counter-memory alive, who permanently dissent in response to the official discourse of denial and silencing, and who deposit their own historical truth into Mexican collective memory.

\section{NOTES}

1. The article is part of a study on the Dirty War and the "war on drugs". Interviews and testimonies were recorded between 2007 and 2014 in different villages in the district of Atoyac de Álvarez, the town of Atoyac de Alvarez (state of Guerrero) and in Mexico City. The research on the Dirty War is based on testimonies of relatives of disappeared people, victims of torture, ex-guerrilla members and human rights activists. The names have been changed to respect some interviewees' wishes for anonymity. I would like to thank R. Benedito Ferrao for the careful revision of the essay.

2. For further information about the history and the development of armed movements in Mexico, see Bellingeri (2003); Bartra (2000); Castellanos (2007).

3. For detailed information about the Dirty War strategies in the Sierra de Atoyac, see Karl (2014a)

4. Díaz, Gloria Leticia, Proceso Edición Especial [POEE] "Tita y la guerra sucia", 35: 8-11.

5. For detailed information about the Mexican transitional justice process, see: Aguayo, Treviño and Pallais (2006); Aguayo and Treviño (2007); Acosta and Ennelin (2006).

6. Ravelo, Ricardo, Proceso [PO] "La Fiscalia Especial: solo buenas intenciones", 20 January 2002. [accessed 03/September/2014].

7. Solís Téllez, Judith, La Jornada [LJ] "Memoria de la guerra sucia en Guerrero", 28 January 2010. [accessed 04/September/2014]

8. See the documentary El Crimen de Zacarías Barrientos (Frankreich, R., 2008. K Production).

9. See photographs: http://www.hijosmexico.org/index-tomate la foto. los desaparecidos nos faltan a todos\#39 [accessed $1 \overline{2 / O c t o b e r / 2014]}$

10. See street-renaming actions: http://www.hijosmexico.org/index-renombrando. [accessed 12/October/2014].

11 For further details about the Rosendo Radilla case, see CMPD$\mathrm{HH}$ and the verdict of the Court:www.corteidh.or.cr/docs/casos/ articulos/seriec_209_esp.doc. [accessed 04/September/2014]. 
12. Díaz, Gloria Leticia. [PO] "Un fiasco, las exhumaciones en Guerrero", 09 August 2008. [accessed 02/September/2014].

13. CMDPDH/Comisión Mexicana para la Defensa y Promoción de los Derechos Humanos (2013): Inician diligencias en Atoyac de Álvarez para encontrar el paradero de Rosendo Radilla Pacheco. http://cmdpdh.org/2013/05/inician-diligencias-en-atoyac-deÁlvarez-para-encontrar-el-paradero-de-rosendo-radilla-pacheco/. [accessed 02/September/2014].

14. Valadéz Luviano, Rodolfo, La Jornada Guerrero [LJG] "Roban a quienes recibieron su indemnización por la guerra sucia, denuncian ante la Comverdad", 22 October 2012. [accessed 03/ September/2014]

15. [LJ] "Una 'pantomima': acciones de autoridades en búsqueda de los normalistas: AI", 8 October 2014. http://www.jornada. unam.mx/ultimas/2014/10/08/una-201 cpantomima201d-acciones-de-autoridades-en-busqueda-de-los-normalistas-ai-933. html. [accessed 10/October/2014].

16. Turati, Marcela, $[\mathrm{PO}]$ "Denuncian bloqueo a labor de forenses argentinos en fosa de Iguala", 12 October 2014. http://www proceso.com.mx/?p=384584. [accessed 12/October/2014].

17 [PO] "Más de 121 mil muertos, el saldo de la narcoguerra de Calderón: Inegi", 30 July 2013. http://www.proceso.com.mx/ $? p=348816$. [accessed 03/September/2014].

18 See:http://aristeguinoticias.com/2602/mexico/lia-limon-da-aconocer-lista-de-26000-desaparecidos//. [accessed 02/September/2014].

19 Hernández Navarro, Luis, The Guardian [TG] "A war on drugs? No, this is a war on the Mexican people", 12 August 2010. [accessed 04/September/2014]

20 Fazio, Carlos, [LJ] "Terrorismo estatal e impunidad", 28 November 2011. [accessed 01/September/2014].

21 Turati, Marcela, [PO] "Mujeres en tiempos del narco", 12 March 2011. [accessed 02/September/2014].

22. UN Report: United Nations Working Group on Enforced or Involuntary Disappearances concludes visit to Mexico, 31 March 2011

23. Díaz, Gloria Leticia, $[P O]$ "Llama ONU a garantizar derecho a la justicia a familiares de desaparecidos", 27 August 2014. [accessed 01/September/2014].

24. For the history, development, claims and activities of the network of the Movement for Peace with Justice and Dignity, see their website: http://movimientoporlapaz.mx/. Also refer to the report of the UN Working Group at http://www.fundar.org.mx/ mexico/pdf/Informe\%20Final\%20CED_MEXICO_fundar serapaz_mpjd.pdf. [accessed 02/September/2014].

\section{REFERENCES}

Acosta, Mariclaire; Ennelin, Esa (2006) "The 'Mexican Solution' to Transitional Justice". In: Transitional Justice in the TwentyFirst Century. Beyond Truth versus Justice, edited by Roht-Arriaza, Naomi and Mariezcurrena, Javier. Cambridge University Press, Cambridge: 94-119.

Afflito, Frank M.; Jesilow, Paul (2007) The Quiet Revolutionaries. Seeking Justice in Guatemala. University of Texas Press, Austin.

Aguayo Quezada, Sergio; Treviño Rangel, Javier (2007) "Fox y el Pasado. La Anatomía de una Capitulación". Foro Internacional, 190, XLVII (4): 709-739.

Aguilar, Rubén; Castañeda, Jorge (2012) Los Saldos del Narco: El Fracaso de una Guerra. Punto de Lectura, Mexico City.

Antillón Najlis, Ximena (2008): La desaparición forzada de Rosendo Radilla en Atoyac de Álvarez, informe de Afectación Psicosocial. Comisión Mexicana de Defensa y Promoción de los Derechos Humanos A. C., Mexico City.

Bartra, Armando (1996) Guerrero Bronco. Campesinos, ciudadanos y guerrilleros en la Costa Grande. Ediciones Era, Mexico City.

Becker, Anne; Burkert, Olga (2008) "Hijos argenmex. Neue Formen und Diskurse der Erinnerung in Argentinien und Mexiko". In Erinnerung macht gegenwart, Analysen und Berichte, edited by Huffschmid, Anne and Krämer, Michael and Gabbert, Karin and Gabbert, Wolfgang. Lateinamerika Jahrbuch 32, Westfälisches Dampfboot, Münster, 104-124.

Beith, Malcolm (2010) The Last Narco. Inside the Hunt for El Chapo, the World's Most Wanted Drug Lord. Grove Press, London.

Bellingeri, Marco (2003) Del agrarismo armado a la Guerra de los pobres. 1940-1974. Casa Juan Pablos, Mexico-City.

Brandes, Stanley (1998) "Iconography in Mexico's Day of the Dead: Origins and Meaning". Ethnohistory 45 (2): 181-218.

Campbell, Howard (2009) Drug War Zone. Frontline Dispatches from the Streets of El Paso and Juárez. University of Texas Press, Austin.

Campbell, Howard (2014) "Narco-Propaganda in the Mexican 'Drug War': An Anthropological Perspective". Latin American Perspectives, 41: 60-77

Castellanos, Laura (2007) México Armado 1943-1981. Ediciones Era, Mexico-City.

CMDPDH/Comisión Mexicana para la Defensa y Promoción de los Derechos Humanos (2010) La Sentencia de la Corte IDH. Caso Radilla Pacheco vs. Estados Unidos Mexicanos. CMDPDH, Mexico City.

Comité 68 (2008) Informe Histórico presentado a la sociedad mexicana: Fiscalía especial FEMOSPP. Serie: México: Genocidio y delitos de lesa humanidad. Documentos fundamentales 19682008, Tomo IX. Comité 68, Mexico City.

Das, Veena and Poole, Deborah (editors) (2004) Anthropology in the Margins of the State. School of the American ResearchPress, Santa Fe.

David, Gary C. and Jalbert, Paul L. (2008): "Undoing Degradation: The Attempted 'Rehumanization' of Arab and Muslim Americans". Ethnographic Studies, 10: 23-47.

Esmeir, Samera (2006): "On Making Dehumanization Possible". Modern Language Association, 121 (5): 1544-1551.

Ferrándiz Francisco (2009): "Fosas comunes, paisajes el terror". Revista de Dialectología y Tradiciones Populares, LXIV (1): 61-94.

Ferrándiz, Francisco (2010) "De las fosas comunes a los derechos humanos: El descubrimiento de las desapariciones forzadas en la España contemporánea". Revista de Antropología Social 19: 161-190.

Gatti, Gabriel (2008) El Detenido-Desaparecido: Narrativas Posibles para una Catástrofe de la Identidad. Ediciones Trilce, Montevideo.

Gómez-Barris, Macarena (2009) Where Memory Dwells. Culture and State Violence in Chile. University of California Press, Berkeley.

Herman, Judith L. (1998) "Recovery from Psychological Trauma". Psychiatry and Clinical Neurosciences 52 (5): 145-150.

Jelin, Elizabeth (2003) State Repression and the Labors of Memory. University of Minnesota Press, Minneapolis.

Karl, Sylvia (2014) "Rehumanizing the Disappeared: Spaces of Memory in Mexico and the Liminality of Transitional Justice". American Quarterly, 66 (3): 727-748

Karl, Sylvia (2014a) Kampf um Rehumanisierung. Die Verschwundenen des Schmutzigen Krieges in Mexiko. Transcript, Bielefeld.

Katz, Friedrich (2006) "La Guerra Fría en América Latina y sus particularidades en México". In Nuevos ensayos mexicanos, edited by Katz, Friedrich. Ediciones Era, Mexico City: 455-473.

Lomnitz, Claudio (2006) Idea de la Muerte en México. Fondo de Cultura Económica, Mexico-City.

López y Rivas (2012) "Viejas y nuevas guerras sucias". El Cotidiano, 172: 116-123.

Maier, Elizabeth (2001) Las madres de los desaparecidos. ¿Un nuevo mito materno en América Latina?. Universidad Autónoma Metropolitana, Mexico City.

Maoz, Ifat/McCauley, Clark (2008) "Threat, Dehumanization, and Support for Retaliatory Aggressive Policies in Asymmetric Conflict". The Journal of Conflict Resolution 52 (1): 93-116.

Marcial Jiménez, Rodrigo (2009) Violencia y narcotráfico en México. Universidad Autónoma del Estado de México, Mexico. 
Mendoza García, Jorge (2011) "La tortura en el marco de la Guerra sucia en México. Un ejercicio de memoria colectiva". Polis: Investigación y Análisis Sociopolítico y Psicosocial, 7 (2): 139-179.

Miranda Ramírez, Arturo (2006) La Violación de los Derechos Humanos en el Estado de Guerrero durante la Guerra Sucia: Una Herida no Restañada. Taller José C.Orozco: Universidad Autónoma de Guerrero, Chilpancingo.

Montemayor, Carlos (2010) La Violencia de Estado en México. Antes y después de 1968. Debate, Mexico City.

Oelofsen, Rianna (2009): "De- and rehumanization in the wake of atrocities". South African Journal of Philosophy 28 (2): 178-188.

Oikión Solano, Verónica and García Ugarte, Marta Eugenia (editors) (2006) Movimientos armados en México, siglo XX. El Colegio de Michoacán/CIESAS, Zamora.

Osorno, Diego Enrique (2009) El cártel de Sinaloa. Una historia del uso político del narco. RandomHouseMondadori, Mexico-City.

Osorno, Diego (2012) La guerra de los Zetas. Viaje por la frontera de la necropolítica. Grijalbo, Mexico City.

Rangel Lozano, Claudia (2011) "La voz de los sobrevivientes: Las cárceles clandestinas en Guerrero, México: una radiografía. 1969-1979". O público e o privado, 18: 75-92.
Reveles, José (2011) Levantones, Narcofosas y falsos positivos. Grijalbo, Mexico City.

Robben, Antonius (2005) Political Violence and Trauma in Argentina. University of Pennsylvania Press, Philadelphia.

Rodríguez Munguía, Jacinto (2007) La otra guerra secreta. Los archivos prohibidos de la prensa y el poder. Debolsillo, Mexico City.

Sáenz Carrete, Erasmo (2001) "Prefacio". In: Las madres de los desaparecidos. ¿Un nuevo mito materno en America Latina?, edited by Maier, Elizabeth. Universidad Autónoma Metropolitana, Mexico City: 15-24.

Sant Cassia, Paul (2007) Bodies of Evidence: Burial, Memory and the Recovery of Missing Persons in Cyprus. Berghahn Books, Oxford.

Scovazzi, Tullio and Citroni, Gabriella (2007) The Struggle against Enforced Disappearance and the 2007 United Nations Convention. MartinusNijhoff, Leiden/Boston.

Sicilia, Javier (2011) Estamos hasta la Madre. Editorial Planeta Mexicana, Mexico City.

Turner, Victor (1967) The Forest of Symbols: Aspects of Ndembu Ritual. Cornell University Press, Ithaka/New York.

Van Gennep, Arnold (1961) The Rites of Passage. University of Chicago Press. 